\title{
Sociology
}

\section{GEOFFREY WOOD}

In his classic work on The Sociological Imagination, C. Wright Mills argued that it 'enables the possessor to understand the historical scene in terms of its meaning for the inner life and external career of individuals' (Mills 1959: 5). In other words, sociology seeks to explain the experience and life chances of the individual in terms of the wider historical and institutional context. Sociological accounts of the nature of democracy and democratization are thus less concerned with the formal constitution of governmental structures than with the effect they might have on the individuals that constitute society in terms of promoting or inhibiting social equality and better life chances, and vice versa. In this chapter, classic and contemporary sociological approaches to understanding democracy and democratization are highlighted, with particular attention being accorded to the post-1989 period.

\section{Classical sociological perspectives on democratization}

Given the central concerns of the sociologist towards democratization, it is inevitable that key practical issues that have concerned sociologists include questions of social stratification, progress and development. The development of classical social theories of democracy can be broadly summarized as in Table 8.1. These categories are not totally watertight; some theorists straddle more than one tradition. All three traditions are centrally rooted in the Enlightenment, with its emphasis on rationality and social progress. 
Table 8.1 Classical (pre-1940) sociological perspectives on democratization

\begin{tabular}{lll}
\hline $\begin{array}{l}\text { Political science/ } \\
\text { rational actor } \\
\text { perspective }\end{array}$ & $\begin{array}{l}\text { Political } \\
\text { Economy } \\
\text { tradition }\end{array}$ & $\begin{array}{l}\text { Interactionist } \\
\text { and consensus } \\
\text { sociological theories }\end{array}$ \\
\hline $\begin{array}{l}\text { Key Theorists } \\
\text { North American } \\
\text { economics/ } \\
\text { political science }\end{array}$ & $\begin{array}{l}\text { Marx, Engels, } \\
\text { Lenin, Frankfurt } \\
\text { School }\end{array}$ & Durkheim, Weber \\
$\begin{array}{l}\text { Perspective on } \\
\text { the state }\end{array}$ & $\begin{array}{l}\text { Marxist theories } \\
\text { of the state: } \\
\text { polyarchy }\end{array}$ & $\begin{array}{l}\text { Democratic state } \\
\text { represents the outcome } \\
\text { of the increased } \\
\text { rationalization } \\
\text { of society and/or the } \\
\text { instrument of } \\
\text { instopment of the } \\
\text { class dominance }\end{array}$ \\
& & $\begin{array}{l}\text { collective consciousness/ } \\
\text { social organization to a } \\
\text { specific level }\end{array}$ \\
\hline
\end{tabular}

However, what distinguishes the classical interactionist and consensus social theories is their close focus on the process of rationalization and the consequences for modes of social organization; the former would, however, place greater importance on the role of human actions, and the latter on objective social structures.

While what is sometimes referred to as the 'political science tradition' emerged from outside sociology, it has had a strong influence on a range of sociologists from North America, most notably in articles published in leading journals such as the American Sociological Review. In recent years, this perspective has become increasingly theoretically sterile, amounting to little more than a commitment to certain methodological assumptions that are central to neoclassical economics, namely that society is made up rational profit-seeking individuals whose behavioural patterns can be readily quantified.

The classic political science explanation for democratization is that, in many respects, it represents 'an accident of 
history that leaves a balance of power or a stalemate - a dispersion of forces and resources that makes it impossible for any one leader or group to overpower all the others' (Olson 2000a: 134). In other words, if the division of society into small autocracies between rival groups and individuals contending for resources is not possible or feasible, then the alternative is to 'work out a framework for mutual toleration' (Olson 2000a: 134). While a fair number of democracies have not resulted from such spontaneous and autonomous transitions, that is because democratization has been imposed from the outside (for example, the democratization of Italy and Germany after the Second World War), and/or because of the influence of an already-democratic state.

In contrast, Marxist theories of the state centred on the view that political life under capitalism is inherently repressive, 'crushing the everyday life, economic life, the real life of individuals' (Lefebvre 1966: 130). In other words, under capitalism, the state is simply there to ensure that favourable conditions for capital accumulation are created. Democratization is not something that is achieved, but an ongoing struggle that can be carried forwards or forced into retreat. The struggle is about going beyond a democratic state to building a society without state power, Marx's communist utopia. Working for democratization is about finding out the truth of politics under capitalism, and seeking to eliminate formal politics altogether (Lefebvre 1966: 138). Thus, while Marx saw the modern capitalist state as more advanced than any previous form of state, it remained imperfect and must be done away with. To Marx, as long as the fundamentals of capitalism remained in place, any apparent element of pluralism in the capitalist state was of little worth.

Finally, classical social theorists such as Max Weber and Emile Durkheim locate democratization in terms of the gradual rationalization of society, and the consequences of this for economic organization. Two main strands can be distinguished here: interactionist and consensus theories. Interactionism is a broad school of thought that is deeply influenced by the writings of Weber. He explored the manner in which individuals interact, and the relationship between changes in belief systems and social behaviour. Weber believed the rise of Protestantism created the conditions for the 
emergence of rational capitalism. In turn, capitalism could not survive without the rational legal administration of the modern bureaucratic state (Giddens 1971: 179). Democratization is closely related to the rise of the latter; there can be no demands for equality before the law, unless the law is a rational and formal code governing behaviour. Yet there is a central tension between democratization and the bureaucratization process; for democratic rights to be exercised, additional bureaucratic regulations are needed. Democracy requires the impersonal selection of individuals in key government posts, a process that will necessarily result in reduced accountability. Yet for Weber, unlike Marx, democratization along multi-party lines was no sham. Democratic societies were characterized by higher levels of equity than those encountered under any other state form. Direct democracy is not possible in mass societies; representational democracy is thus the only option. Under universal suffrage, leaders must have a degree of charisma, encouraging 'Caesarist' tendencies in political leaders. However, that can be checked through vigorous parliamentarianism, which provides the means by which leaders who overstep the mark can be brought to book (Giddens 1971: 181).

Sociologists in the consensus tradition accord somewhat more attention to the evolution of social structures, and the role they play in moulding social behaviour, in building a broad consensus. In many respects, the father of consensus sociology was Emile Durkheim. Durkheim believed that 'as societies become more complex, a major trend is to the emancipation of the individual from the collective conscience', that is from the accumulated bodies of attitudes, norms and values that govern human behaviour (Giddens 1971: 101). In other words, individuals become freer from the straitjacket of tradition and its associated social taboos. Durkheim (1933) maintained that the increase in the division of labour as societies evolve necessarily involves an increase in government. However, associated with the process of development is the emergence of moral ideas that stress the rights and dignities of individuals. These pressures result in the state in most modern societies becoming more democratic, an institution 'primarily responsible for the provision and protection of these individual rights' (Giddens 1971: 101). However, the process of democratization is not 
inevitable or irreversible. It is possible that the activities of the state will expand to a level where they become a repressive agency, a situation that will emerge if the 'secondary groupings' (civil society actors) that intervene between individual and the state, and that serve to counter-balance state power, are not fully developed. Thus, for democratization to be secured, it is necessary that active attention be accorded to developing civil society.

To Durkheim, a society is more or less democratic if there is effective two-way communication between state and society; in mature democracies accepted norms for the conduct of social life take on a conscious or directed character through the actions of the state. In other words, the democratic state can be seen as the 'ego' of society; it is creative and both leads and is led by society (Giddens 1971: 102). Again, civil society groupings have a vital mediating role to play to ensure that the state is not constantly buffeted by day-to-day changes in the popular mood (Giddens 1971: 102).

\section{Democratization secured?}

In the early years of the century, formal democracy in many of the advanced societies was extremely shaky, or even non-existent. The rise of fascism in the 1920s and 1930s led many to conclude that democracy might be little more than a historical anomaly in visible decay, a perspective epitomized in the works of German novelist and social thinker, Erich Junger (1970). However, this was followed by fascism's equally rapid demise (outside the relatively peripheral Iberian peninsula), the redemocratization of much of Western and Central Europe, and the triumph of Keynesian forms of economic management. Not only did predictions of the death of democracy seem equally premature, but also the seemingly unbridgeable social divisions that had led to the crises of the 1930s had apparently been resolved; the bulk of citizens in the advanced societies now enjoyed a standard of living unprecedented in history.

By the late 1960s, evidence of mass discontent, epitomized by escalations in industrial action and student protests, and the glaringly apparent deficiencies of neo-Stalinism led to a 
renewed debate among sociologists as to the most desirable way forward. Among neo-liberal thinkers - a group generally in the minority among sociologists, though not so much so among economists - Nozick (1984) suggested that the only viable way forward was the minimalist 'night watchman state'. However, while conservative politicians were quick to endorse this viewpoint when it came to regulating economic activity, they tended to match this with calls for a greater regulation of social life.

The always richly diverse radical tradition became further fragmented with the rise of a new school of sociological thought, post-modernism. The similarly diverse 'neoenlightenment approach', drawing on the works of a range of classical social thinkers, focused on issues such as the most appropriate means of realizing the goals of the Enlightenment - namely, the rationalization of social life - and the value of classical constructs for social analysis. Some of the principal theoretical strands and developments are summarized in Table 8.2.

Table 8.2 Social theories of democracy, 1968-89

\begin{tabular}{|c|c|c|c|c|}
\hline & $\begin{array}{l}\text { Classical } \\
\text { Political } \\
\text { Economy } \\
\text { approach }\end{array}$ & $\begin{array}{l}\text { Post- } \\
\text { modernism }\end{array}$ & $\begin{array}{l}\text { Neo- } \\
\text { Enlightenment- } \\
\text { based } \\
\text { approaches }\end{array}$ & $\begin{array}{l}\text { Economic/ } \\
\text { political } \\
\text { science } \\
\text { tradition }\end{array}$ \\
\hline $\begin{array}{l}\text { Conception } \\
\text { of the } \\
\text { democratic } \\
\text { state }\end{array}$ & $\begin{array}{l}\text { The state } \\
\text { represents the } \\
\text { apex of the } \\
\text { superstructure } \\
\text { of the } \\
\text { capitalist } \\
\text { mode of } \\
\text { production }\end{array}$ & $\begin{array}{l}\text { The state } \\
\text { represents } \\
\text { a particular } \\
\text { concentration } \\
\text { of power } \\
\text { networks and } \\
\text { domination - } \\
\text { an 'apparatus } \\
\text { of capture' }\end{array}$ & $\begin{array}{l}\text { The state } \\
\text { represents the } \\
\text { product of the } \\
\text { rationalization } \\
\text { of society }\end{array}$ & $\begin{array}{l}\text { Minimalist } \\
\text { state is } \\
\text { desirable to } \\
\text { allow free } \\
\text { reign to } \\
\text { economic } \\
\text { activity and } \\
\text { innovation }\end{array}$ \\
\hline $\begin{array}{l}\text { Way } \\
\text { forward }\end{array}$ & Socialism & $\begin{array}{l}\text { Localized } \\
\text { action; } \\
\text { 'micro- } \\
\text { tribalism' }\end{array}$ & $\begin{array}{l}\text { 'Realization of } \\
\text { Enlightenment } \\
\text { goals'; local } \\
\text { democracy }\end{array}$ & $\begin{array}{l}\text { Minimal } \\
\text { government }\end{array}$ \\
\hline $\begin{array}{l}\text { Principal } \\
\text { theorists } \\
\text { (1968-89) }\end{array}$ & $\begin{array}{l}\text { Althusser, } \\
\text { Poulantzas }\end{array}$ & $\begin{array}{l}\text { Foucault, } \\
\text { Deleuze, } \\
\text { Guattari }\end{array}$ & $\begin{array}{l}\text { Giddens, } \\
\text { Habermas }\end{array}$ & Nozick \\
\hline
\end{tabular}


As Crouch (1979) notes, social theory in the 1970s accorded increasing attention to the role of the state. Within Europe, much of this centred on the Marxist tradition (Table 8.2, column 1). However, within the United States, while political science accorded little attention to developing a systematic social theory of the state, a few scholars such as Robert Dahl explored the issue of community power. Other leading political scientists argued that democratic pressures from below could overload government with excess demands. Huntington (1968), for example, argued this in respect of interest groups and governments. These arguments were followed on by neo-liberal 'political science' writers in the 1980s, who suggested that the easiest way to disarm the insatiable demands of the masses was, quite simply, to do away with the state as a site of patronage.

The relative strength of Marxist contributions in the 1970s reflected Marxism's capacity to draw clear links between political and economic happenings. At the same time, it was seriously weakened by a reluctance to admit any element of pluralism within the capitalist democracies; 'real' democratization was still to happen. The traditional Marxist view was that capitalism was characterized by the domination of a minority, the capitalist ruling class; any democratic participation by the mass of society must thus be little more than a fraud (Callinicos 1997). This insistence seemed increasingly untenable, given that the 1950s and 1960s had seen material gains in the conditions of the working class within the advanced societies, and in the 1970s the crisis of Keynesianism seemed to result in a genuine policy contestation. Despite Marx's claims of historical progress, developments provided little in the way of signposts towards a socialist future that would transcend multi-party democracy (Crouch 1979). Moreover, the ostensibly Marxist states of Eastern Europe presented a most unappealing alternative to Western democracy, and were increasingly running out of economic momentum. To Giddens, the experience of the post-war years revealed capitalism's inherent capacity to reform itself and the space created by the general franchise for a wide range of social issues to be placed on the table, debated, and partially resolved.

To some writers in the Althusserian/French structuralist Marxist tradition, the matter could best be explained by 
highlighting the relative autonomy of the capitalist state. Capitalism is characterized by competition between different fractions or segments, whose interests may conflict, accounting for the significant policy shifts and social compromises (Strinati 1982). However, this perspective provides little room for short-term mass action aimed at expediting social redress and broadening the base of democracy (Crouch 1979), a perspective that would prove politically debilitating to its proponents.

More pragmatically, the British social theorist Ralph Miliband (1972) drew a clear distinction between authoritarianism and liberal democracy - a distinction that was dismissed by most orthodox Marxists at the time. To Miliband, a liberal democratic state is a relatively autonomous actor. The stability of capitalism can best be explained by its flexibility. The system does indeed impart significant power to the working class, enabling real gains to be made, even if the overall capitalist framework remains in place. The apparent weakness and pliability of the capitalist state underscores the need to break with structuralist Marxism, and develop a more dynamic state theory that reflects the realities of liberal democracy. Multi-party democracy thus represents an area of contestation, whose boundaries need to be advanced; democratization is an ongoing and contested process.

Other writers in the radical tradition began moving away from Marxism to alternative Enlightenment approaches, most notably Jürgen Habermas $(1989,1990)$ of the Frankfurt school. Many aspects of Habermas's work had much in common with earlier thinkers, such as Weber, with his emphasis on the relationship between rational discourse and social progress. Provided there is room for the former, social progress is possible on incremental lines, a good example being the growth of the welfare state in Europe in the 1950s and 1960s. Formal democracies generally provide the space for continuous improvement in the way they operate, and enable progress towards a more equitable and inclusive future; again, democratization is an ongoing project, not a process that has been completed.

Limitations with the Marxist model also stimulated a different breakaway, as a number of French writers in the broad Althusserian/structuralist Marxist tradition began to 
experiment with a range of theoretical alternatives. The brief flirtation of many with café Maoism soon gave way to an increasingly influential theoretical paradigm, postmodernism. In contrast to the Marxist preoccupation with class inequality, early post-modernists such as Michel Foucault focused on the workings of power and domination within contemporary society. To Foucault complex power/ knowledge networks underpinned social order, a long-term historical tendency being towards more subtle methods of social control, but social control nonetheless. This would, for example, explain why the formal democratization of Western societies was permitted (Poster 1984). Real democracy - free from hidden control and domination - is only possible through localized activism, creating space for the most marginalized in society 'to speak for themselves'. What makes post-modernist views of democracy so different from the bulk of social thought is that democratization on liberal-pluralist lines is seen as neither inevitable nor desirable. Classical social theorists such as Marx, Weber and Durkheim all saw the democratization of political institutions as the inevitable outcome of social and technological progress (although for Marx this would entail their destruction). This viewpoint is shared by most modernist sociologists. In contrast, for post-modernists formal democratization is a process devoid of meaning, given the persistence of power networks and imbalances. Similarly, there is no reason why societies will necessarily be democratic once they have evolved to a certain stage.

\section{The triumph and decay of democratization}

The resurgence of neo-liberalism in the 1980s, followed by the collapse of Soviet rule in eastern Europe (and of the Soviet Union itself), and the reinstitution of democratic rule in many parts of the 'Third World' sparked renewed debate amongst sociologists as to the relationship between the state and society and the inevitability of democratization. Writing outside the mainstream sociological tradition, Francis Fukuyama (2000: 319), in an influential essay first published in 1989, argued that there was a 'remarkable 
consensus concerning liberal democracy as a system of government', conquering rival ideologies ranging from fascism to communism. Deploying Hegelian theory, Fukuyama argued that, while there may be temporary setbacks, liberal democracy was an idea that 'could not be improved on'; in this sense, history had ended, with the triumph of the most effective and just state form. Fukuyama's arguments were soon seized upon by a range of conservative thinkers, who argued that it was desirable to practice liberal democracy in its purest form - a democratically accountable state that would leave citizens as much room as possible to get on with their lives unimpeded (Table 8.3).

Table 8.3 After 1989 - democracy and current social theory

\begin{tabular}{|c|c|c|c|c|}
\hline Minimalism & $\begin{array}{l}\text { Institutionalist } \\
\text { approaches }\end{array}$ & $\begin{array}{l}\text { Ultra- } \\
\text { leftism }\end{array}$ & $\begin{array}{l}\text { Post- } \\
\text { modernism }\end{array}$ & $\begin{array}{l}\text { Local } \\
\text { democracy/ } \\
\text { theories of } \\
\text { community } \\
\text { action }\end{array}$ \\
\hline \multicolumn{5}{|l|}{ Tradition(s) } \\
\hline $\begin{array}{l}\text { Political } \\
\text { science/Neo- } \\
\text { liberalism }\end{array}$ & $\begin{array}{l}\text { Political } \\
\text { Economy }\end{array}$ & $\begin{array}{l}\text { Political } \\
\text { Economy }\end{array}$ & $\begin{array}{l}\text { Post- } \\
\text { modernism }\end{array}$ & $\begin{array}{l}\text { Classical } \\
\text { Enlightenment/ } \\
\text { Political } \\
\text { Economy/ } \\
\text { Theories } \\
\text { of social } \\
\text { movements }\end{array}$ \\
\hline \multicolumn{5}{|c|}{ Conception of desirable state } \\
\hline $\begin{array}{l}\text { Ultra- } \\
\text { minimalist } \\
\text { state }\end{array}$ & $\begin{array}{l}\text { Institutional } \\
\text { mediation } \\
\text { between } \\
\text { individuals } \\
\text { and } \\
\text { corporations }\end{array}$ & $\begin{array}{l}\text { Realize } \\
\text { goals of } \\
\text { Marx and } \\
\text { Lenin/ } \\
\text { Vanguardist } \\
\text { party }\end{array}$ & $\begin{array}{l}\text { Dissolution } \\
\text { of state; } \\
\text { power in } \\
\text { the hands } \\
\text { of localized } \\
\text { groupings }\end{array}$ & $\begin{array}{l}\text { Local } \\
\text { democracy and } \\
\text { participation; } \\
\text { 'Third Way'; } \\
\text { mediation } \\
\text { between local } \\
\text { and global }\end{array}$ \\
\hline \multicolumn{5}{|c|}{ Principal theorists } \\
\hline $\begin{array}{l}\text { Nozick, } \\
\text { Friedman }\end{array}$ & $\begin{array}{l}\text { Regulation } \\
\text { theorists } \\
\text { (Boyer, } \\
\text { Lipietz); } \\
\text { theorists } \\
\text { of neo- } \\
\text { corporatism } \\
\text { (Streeck) }\end{array}$ & $\begin{array}{l}\text { Callinicos, } \\
\text { Cliff }\end{array}$ & Deleuze & $\begin{array}{l}\text { Giddens, } \\
\text { Habermas, } \\
\text { Castells }\end{array}$ \\
\hline
\end{tabular}


The adoption of neo-liberal macro-economic policies (and, in the US, the distorted 'war Keynesianism' that followed it) in the 1980s led to rising social inequality, primarily due to a widening of the wage gap, rather than increasing unemployment. In other words, while mass political enfranchisement was (at least on the surface) secure, it seemed that the economic disenfranchisement of a significant component of society had returned. Similarly, in many of the emerging 'Third World' democracies, mass participation in the electoral process appeared to do little to correct massive increases in social inequality. In any event it could be argued that the growing political clout of large corporations was increasingly divesting the formal political processes of any real meaning.

Such arguments were bolstered by evidence of a decline in the number of citizens who bothered to vote in most of the mature democracies, the triumph of the 'politics of spin' in the 1990s, and an exponential increase in political campaign spending funded by corporations seeking political access and influence. It can be argued that given the powers of large firms - some with turnovers greater than that of entire nations - some form of institutional mediation is necessary to offset the imbalance vis-à-vis the mass of society. To Matzner and Streeck (1991), a partial solution comprises a series of social accords (a situation sometimes referred to as 'neo-corporatism') entailing centralized bargaining between governments, unions and firms on matters relating to macro-economic policy, successful examples being in countries like Denmark and the Netherlands.

\section{Regulation theory}

A leading paradigm in the revival of institutional approaches has been regulation theory. Regulationists like Jessop see nothing automatic about the periods of stability in capitalist development; rather, this is a product of social agency (Jessop 2001a: ix). Given this, it is possible for institutions to ameliorate the worst excesses of capitalism, and to provide the basis for emancipatory alternatives, inspired by the socialist, ecological, feminist and other social movements. Although originally in the Marxist tradition, regulationism's links with classical Marxism have become increasingly tenuous; nonetheless, regulationism does provide steps to 
resolving the shortfalls of Marxist theory in explaining both the implications of social embeddedness and why Western capitalist states are formally democratic. It should be noted that, to regulationists, stability is not simply underpinned by a series of compromises between capital and labour; the relationship between state and society is also one of contestation and struggle between competing groupings in society.

But what would a regulationist political programme look like? On the one hand, there is the cautious approach. The need to develop a 'post-liberal' - and post-Stalinist - democratic strand fuelled debates within the British theoretical journal, Marxism Today. To writers associated with this journal, such as Martin Jacques, changes in the nature of capitalism land most notably the shift away from traditional forms of mass production) required 'new politics'. This was a critique that 'contributed powerfully to New Labour and Blairism', with its emphasis on a third way (Jessop 2001b: xxii). Others, more within orthodox regulation theory, argued that more vigorous forms of institutional mediation are necessary.

Other writers associated with the regulationist school of thought, such as Lipietz, have argued for a new 'ecological politics', stressing the importance of sustaining the biosphere as a whole. Lipietz places great emphasis on grass-roots alliances between broad social movements as the basis for the cultivation of civic virtues, given the seeming lack of responsiveness of formal democratic institutions (Jessop 2001b: xxii). What both these strands have in common is the recognition that a large component of traditional left politics incorporated an authoritarian streak (Lipietz 2001: 502). Many progressive writers during 1920-1989 forfeited the moral high ground by acting as apologists for Soviet repression, and, in some cases, for the lunacies of Maoism as well. Lipietz (2001: 502) argues that the modern citizen is confronted with 'two leviathans', the market, which is dominated by the wealthiest, and the state, which is exterior to the community and can easily be appropriated by a minority, formal democratization notwithstanding. So again, politics and democratic participation are not simply about the state but involve contestation and compromise between interest groupings at local and national levels. 


\section{Neo-enlightenmentism and post-modernism}

The focus on the rediscovery of civic virtues and the revival of local democracy has been taken even further by a diverse collection of writers from theoretical traditions ranging from neo-enlightenmentism to post-modernism. To Habermas, democratization is about securing social and political progress through rational discourse. Habermas argues that class struggle has only one aim - to create situations where the other side is forced to listen. Human beings are inherently rational, and within the advanced societies there is little alternative to rationality and its inevitably beneficial social outcomes. In his later works, Habermas argued that a particularly fertile ground for rational discourse between different interest groupings is at local level, highlighting the importance of a devolution of powers (Habermas 1990). A contrast is provided by such writers on social movements as Manuel Castells (1998), who writes:

So there is democracy, which is a very important thing, but once we elect our representatives, they have very little capacity to really influence the events along the lines of what they promised to do. The relationship between whom I vote for and what he or she is able to do for me becomes very indirect... we are seeing a growing voiding of representative democracy in the sense of the ability to make a difference in our lives. It's not that democracy is finished, it's only that relationship between political representation and what happens in my life is more and more remote and indirect.

Castells argues that the inevitable response to this is the rise of new social movements, grass-roots organizations uniting people around issues of common concern when formal structures of democratic participation are seen as unresponsive. Whilst arguing that movements have a vital role to play in society, Castells cautions that they might degenerate into narrow and intolerant sectionalist organizations.

A very much more extreme version of this vision is provided by certain post-modern writers, most notably Giles Deleuze. To Deleuze, all states, even formal democracies, are inherently repressive; real progress would involve a deformalization of social relationships, with interactions being purpose-orientated, and not regulated or bound by the complexities of social norms, routines, and underlying power networks (see Deleuze and Guattari 1988: 380). Once 
minorities break free from the 'plane of capital', from seeing themselves in terms of other groupings in society, it is possible to escape existing power networks completely. The reality, however, is that petty nationalist movements have proliferated, in Europe and the developing areas. On the one hand, these movements do constitute attempts to break away from domination by what is perceived to be an alien majority. On the other hand, few of these movements have demonstrated greater tolerance or accountability even towards the minority rights of other groups. Fragmentation of multi-ethnic states has often gone hand-in-hand with ethnic cleansing.

A very different way forward is proposed by the proponents of the 'third way', most closely associated with Giddens. Again, the 'third way' stresses the importance of local participation. However, for Giddens, this should be on very much more formal lines, with the positive feature of central government being retained, and, in some cases, strengthened.

\section{'Third Way'}

Giddens (2000: 4) argues that, in first half of the twentieth century, the major social questions revolved around the consequences of industrialization and accommodating the rise of unions. This led to the rise of tripartism and social accords, solutions that are no longer workable. Instead, given that big institutions can no longer deliver, there is a need to move away from 'bureaucratic top down approaches' favoured by the left. Individuals have to take responsibility for their own fate: this underscores the need to create a favourable climate for wealth creation, not simply emphasizing distribution. To Giddens, this points the way to a 'third way' distinct from statist social democracy and neoliberalism, a new path most closely associated with the Democratic Party in the US and Britain's New Labour. He argues that the 'third way' is not just about a concern with economic development, but also with community issues, and stresses the vital importance of social solidarity and basic social institutions like the family. Right-wing critics of the third way claim it is purely amorphous and avoids hard choices that are necessary if the market is to function with minimal interference. Writers on the left claim that it acquiesces in the failure of governments to stand up to 
the excesses of the market and is silent on rising social inequality.

However, despite the influence of 'third way' thinking neither the Clinton administration in America nor New Labour succeeded in redressing the large-scale social inequality that had re-emerged under previous governments. Moreover, in the desire to attract and retain corporate support there seems little taste for restraining the market (or even for limiting an expansion of its role), even in areas where its failings have become glaringly obvious. Thus, while democratic institutions remain in place, the range of areas where voter preferences can have a significant impact has narrowed.

\section{Varieties of Marxism}

Finally, although their ranks are greatly depleted, there persists a grouping of scholars who remain committed to their interpretation of traditional Marxism, most notably those within the Trotskyist or ultra-left camp. To Callinicos (1997: 206), the Western pluralist state

is not a neutral institution which somehow rises above and regulates society. Ultimately it represents the concentrated and organised force of the capitalist class. This class uses many devices to ensure that the state acts in its interests... and at the core of the state apparatus are the repressive agencies army, police, and intelligence services - which again and again have shown their loyalty to the status quo.

Trotskyists were always outspoken in their condemnation of Stalinism, and so escaped the crisis of confidence that beset other many other strands of Marxism following the collapse of the Soviet Union. To ultra-leftists, full democracy is only possible under socialism. To expedite socialism, it is necessary to have a vanguard party on Leninist lines; the status quo is likely to respond to any challenges in a 'centralized' manner, necessitating clear, coherent and unified strategic responses (Harman 1998). 'Democratic centralism' provides the unity and discipline needed to pursue a democratic struggle, absolute unity and order being necessary to implement decisions that have been democratically discussed - a viewpoint based on a rosy interpretation of the internal life of the Bolshevik party in the pre-Stalin era. Ultra-leftists remain unable or unwilling to accord any worth 
to the formal democratization of political institutions in the advanced societies, despite multi-partyism's superior track record to any other system of government to date. They remain mired in the controversies of the past. To Trotskyists, a vital problem remains to identify the reasons why the Russian revolution degenerated into Stalinism, and how revolutions elsewhere can be more successful, despite the fact that very few revolutions to their liking have taken place since.

A rather different account of the nature and consequences of elite domination is provided in the recent work of Charles Tilly, influenced by both the Marxist tradition and consensus-derived elite theories. Persistent or 'durable' inequality reflects clear social divisions, themselves generated through the operation of social organizations, exploitation being the 'pivotal mechanism' through which inequality is generated (Wright 1999: 7). The deep social embeddedness of social inequality and its constant reconstitution by established organizations will result in the continued marginalization of key segments of society, the mass franchise notwithstanding.

\section{The de-democratization of society?}

In a recent popular volume Noreena Hertz (2001) argues that the power of large corporations has led to the 'death of democracy'; the democratic process has become meaningless, given the unwillingness and inability of governments to restrain the worst excesses of the market. This development has become increasingly apparent to ordinary voters, many of whom seem inclined to withdraw from normal political processes.

Hertz's account is problematic in many ways, not least because it lacks a certain scholarly rigour. It is also problematic in that the experience of democracies continues to be diverse. Electoral participation in many emerging democracies is very high, even where the governments palpably lack the power to regulate adverse market forces. Moreover, despite the crisis of neo-corporatism, countries such as Ireland and the Netherlands continue to operate social 
accords in defiance of neo-liberal conventional wisdom, in opposition to the antipathy of the International Monetary Fund, for instance.

At the same time, Hertz's account does point to a very real crisis in the advanced democracies. Politics in many cases has been divested of meaning. Even where there seems to be overwhelming popular support for non-market solutions - for example in Britain, for the provision of mass transport and health care - governments have been extraordinarily reluctant to embrace them. Political parties appear reluctant to entrust voters with the right to choose between coherent policy proposals, seeking refuge instead in the politics of slogans and soundbites. At the same time the decline of participation in formal politics is matched by the rise of new social movements, most notably the anti-globalization movement and associated campaigns.

The 'compartamentalized' and essentially neo-liberal economic system that the US and Britain exemplify has been foisted on many newly democratized countries in the "Third World'. And more regulated systems such as those in continental Europe and Japan have come under great pressure to be more 'flexible', curtailing the market's accountability to political institutions. At one time proponents of the AngloAmerican model could point to the apparently more robust performance of the US in comparison to more regulated alternatives. This illusion was shattered with the bursting of the internet stocks bubble and global economic slowdown in the early years of the new millennium. That revealed some of the central contradictions of the compartamentalized economy, with the boom of the late 1990s being driven by consumer spending, itself funded by unprecedented levels of household borrowing, at a time of stagnant real wages for all but those in the highest salary bands. This stands in sharp contrast to the Keynesian era, where consumer spending was made possible through redistributive policies. Again, this underscores the nature of the relationship between politics, economy and society in the early 2000s, and the increasing divorce of economic and political elites from the bulk of society. Thus the democratic project remains incomplete. MacEwan, in the aptly titled Neoliberalism or Democracy? (1999: 16) agrees, and furthermore repeats the claim that in the advanced societies democracy is contested. 
To bridge the gap between political elites and society-atlarge, democratic initiatives must make a real difference in people's lives. Existing relations of power and authority must be challenged; greater accountability is essential. More democratic economic development would revitalize political democracy and vice versa.

MacEwan's contribution is a good place to bring this review to a close, for he highlights a central question that has run throughout the chapter: does multi-partyism and the associated institutions familiar in the West constitute a mature or completed process of democratization? Is democratization a journey with a final destination that all societies can eventually reach, or an ongoing process that is unlikely ever to be fully completed? To conservative exponents of politics formal democracy is a completed project in the West - perhaps a manifestation of the 'end of history' so long as the existence of free markets continues. To most current sociologists (post-modernists being the exception) the democratization of the West helped provide and at the same time reflected an unprecedented improvement in the human condition, an improvement that should be emulated worldwide. However, they would hasten to add that democratization is not a one-off 'historical accident'; rather it is an ongoing process. The boundaries of democracy are contested, and need to be further advanced to ensure that a range of social and economic questions of immediate concern to the bulk of society are debated and addressed satisfactorily.

The contested nature of democratization is particularly apparent in those nations where it is a relatively recent phenomenon. To developing states and in large parts of eastern Europe the introduction of political pluralism has coincided with a requirement to implement structural adjustment policies and privatize state assets. Hence voters have very little say as to the manner in which the economy is managed, and the sale of state assets has invariably strengthened the hands of existing elites. This coincidence of formal political empowerment and economic disempowerment leads Perry Anderson (2000) to an ambivalent conclusion. A real process of democratization is taking place on a global scale, even in hitherto unexpected locales such as South Africa and East Timor. But at the same time 
democracy has been 'hollowed out at its core' - in the advanced societies - where debate is 'asphyxiated' by the interests of the political and economic status quo, a trend heightened after the terrorist events of 11 September 2001.

There is little doubt that contemporary sociological theory continues to devote much attention to the nature of democratization and the extent to which political institutions can ever represent the interests of all society. However, not only has there been a tendency for suggested remedies to become more timid and reformist, but also for social theory to become somehow less theoretical. While regulationism and social movement theories continue to locate current debates within a broad political-economy theoretical framework, the latter has become increasingly over-stretched, given the continual modifications to cope with the actual course of events. Much current writing tends to be very issueorientated, eschewing grand theoretical questions that could become mired in the controversies of the past, even in the case of writers such as Giddens, whose earlier works embodied explicit metaphysical pretensions. Finally, although there has traditionally been considerable cross-fertilization between sociology and the disciplines of politics and economics, in recent years this has diminished owing to the growing hegemony of rational choice models within both economics and politics. Rather, sociological perspectives regarding democratization have had greater influence in the emerging trans-disciplines of socio-economics and political economy, which have attempted to break free from the rational choice straitjacket.

\section{Conclusion}

What all these sociological theories have in common is that they seek to understand the nature and desirability of linkages between formal political institutions and the makeup of wider society. In the early years of the twenty-first century there is little doubt that democracy in the advanced societies is at a crossroads. This reflects the re-emergence of the central social question - are current levels of social inequality and uneven political accountability desirable, and 
what is the most acceptable way forward? These questions are posed even more starkly in the newer democracies of Africa, Latin America and eastern Europe. Can democratization be considered to be complete, given that ordinary people have little effective say on a range of central issues concerning economy and society? For the time being, however, there is insufficient pressure for such issues to be fully addressed, unless confidence in the status quo comes to be shaken severely by economic downturn and greater popular pressure emerges within and without the formal political processes. 